\title{
Ortaokul Matematik Ders Kitaplarında Toplumsal Cinsiyet *
}

\section{Gender in Secondary School Mathematics Textbooks}

\author{
Emine ÖZDEMIR**, Ayşe Balcı KARABOĞA***
}

Öz: Bu çalışmanın amacı ortaokullarda okutulan matematik ders kitaplarının içinde yer alan görsellerin cinsiyetçi unsurlar açısından incelenmesidir. Araştırmada ortaokul matematik ders kitaplarında yer alan görsel öğelerde yetişkin kadın ve erkekler ile kız ve erkek çocukların "kimlerle birlikte, hangi cinsiyetten bireylerle, hangi eylemler içerisinde, hangi mekânlarda ve hangi mesleklerde gösterildikleri" incelenmiştir. Araştırmanın örneklemini 2014-2015 eğitim öğretim yılında okutulan MEB ortaokul 5, 6, 7, 8. sınıf matematik ders kitaplarından Mersin İlinde dağıtımı yapılmış olan 4 kitabın görselleri oluşturmaktadır. Bu çalışma nitel bir çalışma olup doküman incelemesi tekniği ile matematik ders kitaplarında yer alan resimler üzerine yapılan bir içerik çözümlemesini içermektedir. Yapılan araştırma sonucunda incelenen ortaokul matematik ders kitaplarının cinsiyetçi öğeleri içerdiği tespit edilmiştir. Ders kitapları bu yolla cinsiyet ayrımcılığının toplumsal yeniden üretimine katkı sağlamaktadır. Ortaokul matematik ders kitaplarında yer alan yetişkin kadın ve erkekler ile kız ve erkek çocuk görselleri toplumsal cinsiyet ilişkileri ile bağlantılıdır. Çalışmada elde edilen en dikkat çekici bulgular ise şu şekildedir: İncelenen ders kitaplarında hem yetişkin ve hem de çocuklarda erkek görsel sayısının kadın/kız çocuk sayısından oldukça fazla olduğu tespit edilmiştir. Yetişkin erkeklerin tek başına resmedilme oranı yetişkin kadınların resmedilme oranının iki katından daha fazladır. Çocuklar açısından yapılan incelemede ailesi ile resmedilme durumu bakımından kızların oranı daha yüksektir. 'Çocuk figürlerin birlikte gösterildikleri kişilerin cinsiyeti' incelendiğinde gerek kız çocuk ve gerekse erkek çocuk figürlerinin daha çok yetişkin erkeklerle resmedildikleri ve kız çocukların hemcinsleriyle resmedilme oranının erkeklerin hemcinsleriyle resmedilme oranından daha düşük olduğu ortaya çıkmıştır. Erkekler daha çok ve çeşitli eylemler içerisinde bulunmaktadır. Bu eylemlerin çoğunluğu da işe yönelik olup eve yönelik herhangi bir eylem içerisinde resmedilmemişlerdir. Kadınlar ise daha çok evde resmedilmişlerdir. Yetişkin figürlerin meslekleri incelendiğinde erkeklerde meslek alanlarının kadınlara oranla çok daha geniş olduğu dikkat çekmektedir.

Anahtar Kelimeler: Ders kitapları, toplumsal cinsiyet, müfredat, gizli müfredat

\begin{abstract}
The aim of this study is to examine the images in secondary school mathematics textbooks in terms of gender. In the study, adult females and males, girls and boys within the visual items in the secondary school mathematics textbooks are examined in terms of "together with whom, from which sex, in which actions, in which places and in which occupations they are shown". The sample of the study consisted of images included in four of the 5th, 6th, 7th and 8th grade mathematics textbooks that were distributed in Mersin Province in the 2014-2015 academic year. This study is a qualitative study and it includes a document analysis technique and a content analysis on pictures in mathematics textbooks. As a result of the research, it was determined that the secondary school mathematics textbooks included elements related to gender discrimination. In this way, it can be said that the textbooks contribute to the social reproduction of gender discrimination. Images representing adult women and men, boys and girls in the textbooks included in the secondary school mathematics textbooks are linked to the gender relations. The most striking findings in the study are as follows: The number of male visuals in both adults and children was considerably higher than the number of women / girls. The percentage of adult
\end{abstract}

\footnotetext{
* Bu makale, "Ders Kitaplarinda Cinsiyetçilik: Ortaokul Matematik Ders Kitaplari Üzerine Bir İçerik Analizi" başlıklı yüksek lisans tezinden üretilmiştir.

** Sorumlu Yazar, Doktora Öğrencisi, Mersin Üniversitesi Eğitim Bilimleri Enstitüsü, Mersin, Türkiye, ORCID: 0000-0003-1706-0264, e-posta: emineuzun46@gmail.com

*** Prof. Dr., Mersin Üniversitesi, Eğitim Fakültesi, Mersin, Türkiye, ORCID: 0000-0003-3958-6582, e-posta: aysebalci@gmail.com
} 
men pictured alone is more than twice of the percentage of adult females pictured alone. The examination of child pictures showed that the rate of girls pictured with their family is higher than boys. When the 'gender of the people with whom' the child figures are shown is examined, it is observed that both the girl and the boy figures are mostly depicted with adult men and the figure of the girls pictured with their own gender is lower than that of the boys pictured with their own gender. Men are more involved in various actions. The majority of these actions was also work-related and was not pictured in any domestic action. Women are mostly portrayed at home. When the occupations of adult figures are examined, it is noteworthy that in men, occupations are much wider than in women.

Keywords: Textbooks, gender, curriculum, hidden curriculum

\section{Giriş}

Fırsat eşitsizliği bireylerin bazı toplumsal haklardan eşit bir şekilde yararlanamamaları anlamına gelmektedir. Cinsiyet, 1rk, dil, din ve sosyal sınıf bakımından ortaya çıkan farklılıkların bu eşitsizliklere konu olduğu düşünülmektedir. Bireyler doğarken ailesini veya cinsiyetini seçme şansına sahip değildir. Ancak hangi ailede ya da toplumda yer aldığına bağlı olarak sahip oldukları özellikleri açısından toplumdaki statüleri belirlenmekte ve buna bağlı olarak da toplumsal olanaklardan yararlanma açısından çeşitli eşitsizlik konumları ortaya çıkmaktadır. Bu toplumsal eşitsizliklerin en belirgin alanlarından birini cinsiyet oluşturmaktadır. Toplumsal cinsiyet kalıpyargıları, ataerkil yapılar ve bütün bunların yeniden üretilmesine yardım eden aile, sosyal çevre, medya ve okul gibi yapılar kadın ve erkeklerin toplumsal olanak ve kamu imkanlarından yararlanabilmeleri açısından çeşitli engeller ortaya çıkarabilmektedir. Eğitim kurumlarındaki etkileşim süreçlerinde ve uygulamalarda olabildiği gibi ders materyallerinin kendisi de rol modelleri sunması, bir cinsiyete yönelik ayrıcalıkları vurgulayabilmesi açısından cinsiyet eşitsizliklerinin yeniden üretildiği ve gözlemlenebildiği bir alan oluşturmaktadır.

$\mathrm{Bu}$ çalışmada ders kitaplarında var olan fakat birçoğumuzun farkında bile olmadığı, normal kabul edip içselleştirdiği cinsiyetçi öğeler üzerinde durulacak ve formal eğitim sisteminde cinsiyetçilik konusu, eğitimde cinsiyet kalıpyargılarına dayalı branşlaşmanın tipik örneklerinden olan matematik alanına ait ders kitaplarının analizine dayalı olarak incelenecektir. $\mathrm{Bu}$ çerçevede öncelikle cinsiyet ve toplumsal cinsiyet tanımları, mevcut araştırmanın teorik çerçevesi, cinsiyet eğitim ve müfredat ilişkileri ve ders kitaplarında cinsiyetçilik kavramları ele alınacaktır. Ardından ortaokul matematik ders kitaplarında cinsiyetçi öğelerin yer alıp almadığı, varsa ne düzeyde yer aldığı ve kitaplarda cinsiyetçi öğelerin nasıl temsil edildiği incelenecektir.

Dünyada olduğu gibi, Türkiye'de de kadınların pek çok alanda erkeklerden dezavantajlı bir konumda yer aldıkları bilinmektedir. Kadınların erkeklerden dezavantajlı oldukları alanlardan birisi de eğitim alanıdır. Kadınlar ile erkeklere atfedilen toplumsal roller ve konumlar bir ölçüde toplumsal yaşamın örgütlenme prensiplerini de belirlemektedir. $\mathrm{Bu}$ kategoriler cinsiyetlerin birbirlerinden farklılıkları üzerine temellenmektedir. Toplumların pek çoğunda erkeksi özellikler ve erkeklerle ilgili etkinlikler üstün konumlarla eşleştirilebilmektedir (Francis, 2006). Kadınlara özgü farklılıklar ise eksiklik olarak görülmektedir (Hayes, 2012). Bu yüzden, öncelikle eğitime önem verilmesinin, kız ve erkek bütün çocukların eğitime erişiminin sağlanmasının ve daha sonra da eğitimde yer alan cinsiyetçi öğelerin ayıklanmasına yönelik çalışmalar yapılmasının; kamusal alandaki pek çok konuma erişimde engel oluşturan cinsiyetlere özgü kalıp yargılarının aşılabilmesinde olumlu sonuçlar vereceği düşünülmektedir.

\section{Cinsiyet ve toplumsal cinsiyet}

Bu terimi sosyolojiye kazandıran Oakley'e (1972) göre, 'cinsiyet' (sex) biyolojik erkek-kadın ayırımını anlatırken, 'toplumsal cinsiyet' (gender) erkeklik ve kadınlık arasındaki toplumsal bakımdan eşit olmayan bölünmeyi ifade etmektedir. Türköne (1995) "gender" ve "sex" kelimelerinin yerine Türkçe karşıllğı olarak, "cinsiyet" ve "cins" kelimelerini kullanmaktadır. Türköne'ye göre cins, biyolojik olarak dişiliği ve erkekliği ifade ederken, cinsiyet biyolojik anlama ilaveten sosyokültürel özellikleri de içermektedir. Dökmen (2004) ise batılı modeller gibi "sex" için cinsiyet, "gender" için "toplumsal cinsiyet" kavramlarını kullanmakta; cinsiyetin, bireyin biyolojisine göre belirlenen bir kategori, toplumsal cinsiyetin ise kadın veya erkek 
olmaya yönelik toplumun veya kültürün yüklediği anlamları ve beklentileri ifade ettiğini söylemektedir. Benzer şekilde Francis (2006) de toplumsal cinsiyetin biyolojik cinsiyetten farklı olduğunu belirtmektedir.

Toplumsal cinsiyet kavramı içerisinde yer alan roller ülkeden ülkeye, toplumdan topluma değişmektedir. Her toplumun süregelmiş çeşitli cinsiyet normları mevcuttur. Çocuklar sosyalleşme sürecinde rollerini çeşitli öğrenme yollarıyla öğrenerek sürdürmekte ve bunun sonucunda da toplumsal cinsiyetin yeniden üretilmesi sağlanmaktadır.

Alanyazın incelendiğinde konuyla ilgili olarak bazı çatı bakış açılarının bulunduğu dikkat çekmektedir. Bunlardan biri olan Thompson'un (2003) sınıflandırmasına göre cinsiyet tanımlarına ve eğitim cinsiyet ilişkilerine liberaller ve radikaller olmak üzere iki perspektif üzerinden bakmak mümkündür. Liberal bakış açısı kendi içerisinde cinsiyet farklılığı ve rol (sosyalleşme teorisi) teorilerini barındırmakta; radikal bakış açısı ise yapısalcılık ve yapı sökümcüler olarak iki farklı görüş açısını içermektedir. Radikal bakışa göre toplumda yer alan maskülen ve feminen değer sistemleri bir yandan cinsiyetçilik sistemini desteklerken diğer yandan ırkçılık, sınıf hiyerarşisi, heteroseksizm ve eşitsizliğin diğer formlarını da beslemektedir (Thompson, 2003).

Dökmen'e (2004) göre, kadın ve erkeklerin doğuştan gelen birbirlerinden farklı yapısal ve fiziksel özellikleri vardır. Örneğin kadınlar ve erkeklerin kromozom sayıları, hormonları, üreme fonksiyonları ve vücutlarının genel yapısı onların biyolojik olarak farklı olduklarını gösteren unsurlardır. $\mathrm{Bu}$ ve bunun gibi diğer özellikler cinsiyet farklılığına sebep olmaktadır. Cinsiyet farklılığ teorisi buradan yola çıkmıştır. Skelton'a (2006) göre cinsiyet farklılığı teorisi kadın ve erkeklerin doğuştan farklı yeteneklere sahip olduklarını savunan bir görüştür. $\mathrm{Bu}$ teoriye göre kadın ve erkekler sonradan öğrendikleriyle değil içgüdüsel olarak doğuştan kazandıklarıyla hareket ederler. Buna karşın rol (sosyalleşme) teorisinde ise MacNaughton'a (2006) göre çocuklar erken yaşlarda cinsiyeti değil, cinsiyet rollerini öğrenmektedirler. Bu teoriye göre toplumsallaşmayı sağlayan bazı öğeler vardır. Aile, arkadaş, kitle iletişim araçları ve okul bunların en temel olanlarıdır. Bu öğeler toplumsal yargıların aktarılmasını gerek doğrudan ve gerekse dolaylı yollardan sağlamaktadırlar. Çocuklar küçük yaşlardan itibaren aile içerisinde kendilerine öngörülen rollerini öğrenmeye başlamaktadırlar. Daha sonra bu öğrenme arkadaşlık ilişkileri ile pekişmeye başlamakta ve okullarda da çeşitli yollarla devam etmektedir.

Çocuklar aile içinde anne ve babayı taklit ederek kadın ve erkek rollerini öğrenmektedirler. Aynı zamanda akranlarından ve medyadan da öğrenme başlamaktadır. Çocuklar, televizyonda izledikleri reklamlar, çizgi filmler ve diziler yoluyla cinsiyete özgü kodları ve çeşitli davranışlar kazanmaktadırlar. Daha sonra okulda da bu öğrenme sürecini devam ettirmektedirler. Okulda uygulanan müfredat ve buna hizmet eden diğer etkenler yani öğretmenler, yöneticiler, materyaller ve ders kitapları yoluyla cinsiyet rolleri öğretilmektedir.

\section{Cinsiyet, eğitim ve müfredat}

Tezcan'a (1985) göre, eğitim eşitliğini engelleyen çeşitli toplumsal etmenler vardır. Bunlardan bir tanesi de cinsiyet ayrımıdır. Gelişmiş ya da gelişmekte olan her ülkede kadınlar erkeklere oranla daha düşük bir düzeyde eğitim almaktadırlar. Eğitime erişim kadar eğitimde cinsiyet eşitliğine yönelik tartışmaların önemli bir kısmını eğitim programları oluşturmaktadır. $\mathrm{Bu}$ konudaki temel düşünce eğitimcilerin özellikle örtük müfredat aracıllı̆̆1 ile öğrencilere cinsiyetçilik içeren mesajlar sunmalarıdır. Çoğunlukla farkında olmadan işleyen bu süreçte eğitimciler kadar kullanılan eğitim materyali ve ders kitaplarının da önemli bir role sahiptir. Her ülkenin eğitim sisteminde her okul türü ve her bir ders için sınıf seviyelerine uygun olarak belirlenmiş amaç ve kazanımlar söz konusudur. Bu kazanımlar okul türü, dersin içeriği ve öğrencinin yaşı da göz önüne alınarak ülkelerin eğitim bakanlıklarınca belirlenmektedir. Belirlenen bu kazanımlara, içeriklere, öğretim durumlarına müfredat denir. Ülkeler müfredat belirlerken çeşitli amaçlara göre hareket etmektedirler. Bu amaçların en başında ise mevcut toplumsal düzenin devam ettirilmesi gelmektedir. Bu ise zaman zaman yazılı olarak belirlendiği gibi genellikle gizli (örtük) olarak da yapılmaktadır (İnal, 2004). Ders kitapları dikkatli olarak incelendiğinde gizli müfredatın içeriğini oluşturacak pek çok öğenin farkına varılabilir. Örneğin 
kitaplardaki görsellerin veya yazılı metinlerin cinsiyetçi öğeler içermesi mümkün olabilmektedir. Bu duruma ilkokul 1. sınıftan lise son sınıfa kadar olan birçok branşta pek çok kitapta rastlamak mümkündür. Kitaplarla birlikte her dersin içeriğine göre önceden belirlenen kazanımların yanı sıra okuyucunun hiç farkına varmadan içselleştirebileceği düşünülen cinsiyet ayırımına ilişkin unsurlar araştırmacılar tarafından fark edilmiş olup birçok ülkede ders kitaplarındaki cinsiyetçi öğelerin varlığını ispat eden sayısız araştırma yapılmıştır ve halen yapılmaktadır. Çoğunlukla sözel alana ait yapılan bu çalışmalarla belirlenen bu durumun fen ve matematik kitaplarında da olabileceği düşünülmüş ve bu çalışmanın yapılması kararlaştırılmıştır.

\section{Ders kitaplarında cinsiyetçilik}

Ders kitaplarında cinsiyetçilik konusu Türkiye'de birçok araştırmaya konu olmuştur. Çalışmalar daha çok ilkokul düzeyi kitaplarına ve Türkçe başta olmak üzere sözel ders kitaplarına yönelik yapılmıştır. $\mathrm{Bu}$ araştırmalardan başlıcaları ilköğretim okullarında okutulan Türkçe ders kitaplarına yönelik olanlar (Esen Severge, 1998; Esen ve Bağlı; 2002, Güvenli ve Uğur Tanrı̈ver, 2009; Kırbaşığlu Kılıç ve Eyüp, 2011; Kitiş Çınar, 2013) ile Asan'ın (2006), Vatandaş'ın (2011), Gümüşoğlu'nun (2008), Can'ın (2009), Yorgancı'nın (2008), Demirel'in (2010), Topal'ın (2012), Özkan'ın (2013), Tanrı̈̈ver'in (2003), Çubukçu ve Sivaslıgil'in (2007) ve Köseler' in (2009) diğer ders kitaplarıyla ilgili olarak yapmış oldukları toplumsal cinsiyetin inşasının çocukların ders kitapları, yardımcı kitaplar ve hikâye kitaplarına yansıyan taraflarını belirlemeyi amaç edinen çalışmalardır. Bu çalışmalar sonucu ortaya çıkan bulguların birbirleriyle yakın ilişkili ve hatta bazılarında ise tamamen aynı olduğu gözlenmiştir.

Ders kitaplarında cinsiyetçilik konusu Türkiye dışındaki diğer ülkelerde de birçok araştırmaya konu olmuştur (Anderson ve Hamilton, 2005; Mineshima, 2008; Taylor, 2003; Weitzman, Eiffel, Hokada ve Ross 1972; Zeenatunnisa,1989; Zinec, 2000). Bu çalışmalarda genel olarak eğitimin amacının yalnızca erkeklerin, avantaj ve firsatlarını en üst düzeye çıkarmaya yönelik olduğu sonucuna, ders kitaplarında, kadınların sosyal statülerinin değişimi ve gelişimine yönelik bir anlayışın yer almadı̆̆ı; kadınların, bağımlı, boyun eğen, korunmaya muhtaç, duygusal, iyi huylu ve zararsız oldukları; zeki olmadıkları, evle ilişkilendirilen, çocuklara şefkat ve ilgi gösteren ve onları besleyen, çocuk bakımı ve çocuğun yetiştirilmesinden sorumlu olan ve bütün bunları yanında cinsel obje olarak gösterildikleri konusuna dikkat çekilmiştir. Bu çalışmalarda ayrıca kadınların en sık ortaya çıkan davranış özelliğinin pasiflik olduğu, kadınların ev içinde yaptığı üretim ve çalışmaların ders kitaplarının içeriğinde, cinsiyetleri gereğince normalleştirildiği vurgulamaktadır. Kitaplarda kız çocukları ya görünmez kılınmakta ya da pasif, şefkatli ve giyinip süslenen cins olarak görülmektedir. Çocukken hareketli, becerikli, aktif ve yetenekli olan kız çocuklarının anne ya da ev kadını olduktan sonra, profesyonel hayattan uzaklaştıkları, pasif rollerde kendilerini belli bir alan ve çevreyle sinırladıkları belirtilmiştir.

Buna karşın incelenen bu araştırmalara göre ders kitaplarında erkekler bağımsız, baskın, zeki, mantıklı, hırslı ve aktif, acıya dayanıklı ve güçlü, kararlı ve bağımsız bireyler olarak gösterilmiş̧lerdir. Çalışma kapsamındaki kitaplarda babanın çocukla etkileşiminin anneye göre daha az olduğuna işaret edilmiştir. Erkek ev dişı, tüm alanlarda gösterilmiştir. Genel olarak çocuk bakımı ve çocuğun yetiştirilmesinden anne sorumlu tutulmakta ve babalar bu alanlarda hiç gösterilmemektedir. Ayrıca bu çalışmalarda erkek çocukların yetenekli, zekâca kızlardan daha üstün, hareketli ve maceracı olarak gösterildikleri belirtilmiştir.

Sadece Mineshima (2008), Japon orta derece okullarında, ders kitabı olarak okutulan İngilizce ders kitapları üzerine yaptığı çalışmasında, kadın ve erkek karakterlerin sayısında, ifade ve rollerinde, kitabın başından sonuna kadar eşit biçimde yer verildiği bulgusuna ulaşılmıştır. Her iki cinsiyetin kitapta her bakımdan dengeli bir biçimde yer aldığını vurgulayan Mineshima, okulla ilgili konularda, mesleki alanda ve aile içi görev ve sorumluluklar konusunda yine iki cinsiyete eşit yer verildiğini belirtmektedir. 


\section{Araştırmanın Amacı}

Türkiye'deki her okulda Milli Eğitim Bakanlı̆̆ı'nca önceden belirlenmiş olan aynı kitapların (aynı ders ve sinıf seviyelerinde ise) kullanılması zorunludur. Okutulacak bu kitapların içerisinde cinsiyetçi öğeler yer alabilmekte ve örtük müfredat aracılığı ile öğrencilere transfer edilebilmektedir. Türkiye'de ders kitaplarında cinsiyetçi öğelere yer verilip verilmediği konusuna ilişkin çalışmaların daha çok sosyal bilimler alanındaki ders kitapları üzerine yapıldığı görülürken; sayısal alandaki ders kitaplarına ait araştırmaların oldukça sınırlı olduğu tespit edilmiştir. Bu nedenle matematik ders kitaplarında da cinsiyet ayrımına yönelik unsurların olup olmadığını araştırmak üzere bu çalışmanın yapılmasına karar verilmiş ve bu çalışmada cinsiyetçi öğeler konusunun ortaokul matematik ders kitaplarına nasıl yansıdığını incelemek amaçlanmıştır.

\section{Yöntem}

\section{Araştırma modeli}

$\mathrm{Bu}$ çalışma nitel bir çalışma olup doküman incelemesi tekniği ile matematik ders kitaplarında yer alan resimler üzerine yapılan bir içerik çözümlemesini içermektedir. Dokümanlar nitel araştırmalarda önemli bilgi kaynaklarıdır. Araştırmalarda hangi dokümanların önemli olduğu araştırma problemi ile yakından ilgilidir. Örneğin eğitim ile ilgili bir araştırmada veri kaynağ 1 olarak ders kitapları, öğretim programları ve eğitimle ilgili diğer resmi belgeler kullanılabilmektedir (Yıldırım ve Şimşek, 2005). Aydın'a (2015) göre de fotoğraflar, videolar veya okunabilen diğer nitel veriler, içerik analizi yapmak için uygundur.

Yıldırım ve Şimşek'e (2013) göre, içerik analizinde temel amaç toplanan verileri açıklayabilecek kavramlara ve ilişkilere ulaşmaktır. Çalışmada doküman incelemesi yoluyla veri toplanmış ve toplanan verinin analizi içerik çözümlemesi yoluyla yapılmıştır. Yıldırım ve Şimşek'e (2013) göre betimsel analizde özetlenen ve yorumlanan veriler bu analizde daha derin bir işleme tabi tutulur ve betimsel bir yaklaşımla fark edilmeyen kavram ve temalar içerik analizi sonucu keşfedilebilir. Bu amaçla toplanan verilerin önce kavramsallaştırılması daha sonra da ortaya çıkan kavramlara göre mantıklı bir biçimde düzenlenmesi ve buna göre veriyi açıklayan temaların saptanması gerekmektedir. İçerik analizinde temelde yapılan işlem birbirine benzeyen verileri belirli kavramlar ve temalar çerçevesinde bir araya getirmek ve bunları okuyucunun anlayacağı bir biçimde düzenleyerek yorumlamaktır. Bu çalışmada da veriler belirli temalar altında toplanarak analiz edilmiş ve yorumlanmaya çalışılııştır.

\section{Örneklem}

Araştırmanın örneklemi ise 2014-2015 eğitim öğretim yılında Mersin İli Toroslar ilçesi İbrahim Karaoğlanoğlu Ortaokulu'nda kullanılan ve aşağıda belirtilen MEB ortaokul 5, 6, 7, 8. sınıf matematik ders kitaplarının görsellerinden oluşmaktadır. Ders kitapları ile ilgili bilgiler şöyledir:

1- Ortaokul matematik ders kitabı 5. Sınıf (Mutluoğlu, Gökbaş ve Kaleci, 2014). (MEB Talim ve Terbiye Kurulu'nun 29/11/2013 tarih ve 155 say1l kurul karariyla 2014/2015 öğretim yılından itibaren 5 yıl süreyle ders kitabı olarak kabul edilmiştir.)

2- Ortaokul matematik ders kitabı 6. Sınıf (Savaşkan, 2014). (MEB Talim ve Terbiye Kurulu'nun 30/05/2014 tarih ve 39 sayılı kurul kararıla 2014/2015 öğretim yılından itibaren 5 yıl süreyle ders kitabı olarak kabul edilmiştir.)

3- Ortaokul matematik ders kitabı 7. Sınıf (Aydın ve Beşer, 2013). (Bu kitap MEB Talim ve Terbiye Kurulu'nun 20/12/2010 tarih ve 264 sayll kurul karariyla 2011/2012 öğretim yılından itibaren 5 yıl süreyle ders kitabı olarak kabul edilmiştir.)

4- Ortaokul matematik ders kitabı 8. Sınıf (Çebi, Bayar ve Çebi, 2014). (Bu kitap MEB Talim ve Terbiye Kurulu'nun 18/12/2009 tarih ve 272 say1l kurul kararıly 2010/2011 öğretim yılından itibaren 5 yıl süreyle ders kitabı olarak kabul edilmiştir.) 


\section{Verilerin toplanması}

$\mathrm{Bu}$ çalışmanın verilerini yukarıda belirtilen MEB ortaokul 5, 6, 7, 8. sınıf matematik ders kitaplarının görselleri oluşturmaktadır. Veriler toplanırken ilk olarak ders kitapları elde edilmiştir. Daha sonra bu kitaplar her kategori için ayrı ayrı genel bir incelemeye tabi tutulmuştur. Atatürk resimleri ve temaları inceleme dışı bırakılmıştır. İnceleme sırasında incelenecek olan kategoriler belirlenmiştir. Belirlenen kategoriler için ders kitaplarında karşılaşılan her kadın/erkek yetişkin figürleri ile kız/erkek çocuk figürlerine ait görsellere yönelik sınıflar bazında rubrikler hazırlanmıştır. Sonrasında da bu veriler bilgisayar ortamına aktarılarak çalışmadaki tüm değerlendirmeler bu rubrikler üzerinden yapılmıştır. Excell programı kullanılarak verilerin dağılımını göstermek için ayrı ayrı tablo ve grafikler oluşturulmuştur.

\section{Veri analizi}

Veriler analiz edilirken içerik analizi yapılmıştır. Sırasıyla verilerin kodlanması, temaların bulunması, verilerin kodlara ve temalara göre düzenlenmesi, tanımlanması ve bulguların yorumlanması aşamaları izlenmiştir.

Matematik ders kitapları incelenirken Esen Severge'nin (1998) geliştirdiği kategoriler yazarın kendisinden izin alınarak temel alınmıştır. Bu kategoriler tekrar gözden geçirilmiş veri analizi boyunca oluşan yeni kategoriler ve alt kategoriler de dikkate alınmıştır.

Esen Severge resim incelemesi yaparken dört ana kategori kullanmıştır. Bu kategoriler çocuk ve yetişkin figürlerin kiminle birlikte, hangi mekânlarda, hangi eylemlerde ve son olarak da hangi nesnelerle birlikte gösterildikleri kategorileridir. Esen Severge (1998) çalışmasında her kategoriyi yine iki alt kategoriye (yetişkin ve çocuk kategorileri) ayırmış ve bu şekilde ayrı ayrı inceleme yapmıştır. Mevcut çalışmada da kategoriler yine aynı şekilde ikişer alt kategori halinde, yetişkin ve çocuk figürleri birbirinden ayrı incelenmiştir.

$\mathrm{Bu}$ çalışmada incelenecek olan ortaokul matematik kitaplarının içeriğindeki görseller Esen Severge'nin kategorilerinden sadece üç tanesi (çocuk ve yetişkin figürlerin kiminle birlikte, hangi mekânlarda ve hangi eylemlerde gösterildikleri kategorileri) alınmış olup bunlara ek olarak mevcut çalışmaya Esen Severge'nin izni ile yeni oluşturulan 'yetişkin ve çocuk figürlerin birlikte gösterildikleri kişilerin cinsiyetleri' ve 'yetişkin figürlerin olası meslekleri' kategorileri ilave edilmiştir. Yetişkin ve çocuk figürlerin birlikte gösterildikleri kişilerin cinsiyetleri kategorisi de yine yetişkin ve çocuklar olarak iki alt kategoride incelenirken meslek konusunda "çocuklar" alt kategorisine yer verilmemiştir. Çalışmada oluşturulan ve incelenen bütün kategoriler ayrıntılı olarak aşağıda tanımlanmıştır.

Bunun dışında Esen Severge (1998) çocuk ve yetişkin figürlerin hangi nesnelerle gösterildiklerine de yer vermiş fakat mevcut çalışmada bu kategoriye yer verilmemiştir. Durumun daha iyi anlaşılması açısından aşağıdaki tablo oluşturulmuştur.

Tablo1.

Esen Severge'nin Kategorileri ile Mevcut Çalışmanın Kategorilerinin Karşılaştırılması

\begin{tabular}{ll}
\hline Esen Severge'nin Kategorileri (1998) & Mevcut Çalışmanın Kategorileri \\
\hline Çocuk ve Yetişkin Figürlerin; & Çocuk ve Yetişkin Figürlerin; \\
1- Birlikte Gösterildiği Kişiler & 1- Birlikte gösterildiği kişiler, \\
2- Figürlerin Gösterildiği Eylemler & 2- Figürlerinin Birlikte Gösterildikleri Kişilerin \\
3- Figürlerin Gösterildiği Mekânlar & Cinsiyetleri \\
4- Figürlerin Gösterildiği Nesneler & 3- Figürlerin Gösterildiği Eylemler \\
& 4- Figürlerin Gösterildiği Mekânlar \\
& 5-Figürlerin Gösterildiği Yetişkin Kadın ve \\
& Erkek Figürlerinin Olasi Meslekleri \\
\hline
\end{tabular}

Bunun yanı sıra Esen Severge'nin çalışmasında Atatürk resimleri ve temaları güncel olmayan görseller içerdiği için çalışma dışında tutulmuştur. Bu çalışmada da Atatürk resimleri 
ve temaları çalışma dışında tutulmuş̧tur. Ayrıca kitapta yer alan portreler de bu çalışma dışında tutulmuştur. Çalışmada hem fotoğraflara hem de çizim biçimindeki görsellere yer verilmiştir. Kategorilerin tanımlanmasında Esen Severge'nin (1998) çalışmasındaki tanımlara sadık kalınmıştır. Bulguların sunumunda tablolarda verilen örnekler ise mevcut çalışmanın verilerinden oluşturulmuştur. Bu çalışmaya özgü olarak ortaya çıkan kategoriler de ayrıca eklenmiştir.

\section{Bulgular ve Tartışma}

Kitaplarda ilk olarak "yetişkin kadın ve yetişkin erkek figürlerinin kimlerle birlikte resmedildikleri"'ne bakılmıştır. Bu doğrultuda Tablo 2 hazırlanarak yetişkin figürlerin kimlerle birlikte gösterildiğine ilişkin dağılım aşağıda belirtilmiştir.

Tablo 2.

Yetişkin Figürlerin Kimlerle Birlikte Gösterildiğine İlişkin Dağılım

\begin{tabular}{lcc}
\hline Yetişkin figürler kimlerle & Yetişkin Erkek Figürler & Yetişkin Kadın Figürler \\
birlikte gösterilmektedir? & 10 & 2 \\
\hline Çocuklarla & 28 & 13 \\
Yetişkinlerle & 8 & 10 \\
Çocuk ve Yetişkinlerle & 3 & 3 \\
Ailesi ile & 2 & 2 \\
Kalabalık İle & 86 & 47 \\
\hline Toplam & & \\
\hline
\end{tabular}

Tablo 2 incelendiğinde genel olarak her iki cinsiyette de yetişkinlerin en fazla tek başına resmedildikleri görülmektedir. Esen Severge'nin 1998 yılında Türkçe ders kitapları üzerine yaptığı çalışmasında kadınların en çok çocuklarla, erkeklerin ise en çok yetişkinlerle resmedildiği sonucuna ulaşmıştır. Sonuçlar açısından mevcut çalışmada farklılıkların ortaya çıkması ders kitaplarındaki cinsiyetçi unsurların azaldığı yönünde bir izlenim vermektedir. Ayrıca kadınların en çok çocuklarıyla resmedilmesi ve kadınların tam da toplumsal rollerine uygun gösterilmesi ve bu yargının sürdürülmesi açısında çok önemli bir öğeyken (Esen Severge, 1998) mevcut çalışmada incelenen matematik ders kitaplarında kadınların en çok çocuklarla değil 'tek başına', sonra yetişkinlerle ve üçüncü olarak yine çocuklarla değil çocuk ve yetişkinlerin bir arada resmedilmesi bir diğer olumlu tespit olarak ortaya çıkmaktadır ve bu kategorilerde bulunan sonuçlar açısından Esen Severge'nin (1998) çalışmasından farklılık göstermektedir.

Kadın ve erkeklerin kimlerle birlikte resmedildiklerine ilişkin sonuçlarda ilk üç sıralama kadın ve erkek figürler için aynı olsa da (en çok tek başına, sonra yetişkinlerle ve üçüncü olarak da çocuk ve yetişkinlerle) yetişkin erkeklerin tek başına resmedilme oranının yetişkin kadınların resmedilme oranının iki katından fazla olması, tek başına olabilme ya da bağımsız hareket edebilme özelliğinin erkeklere atfedilen toplumsal cinsiyet kalıp yargılarını hatırlatması açısından düşündürücüdür.

Aşağıda yer alan Tablo 3'te kız ve erkek çocuk figürlerin birlikte gösterildikleri kişilerin sınıflar bazında dağılımlarına ter verilmiştir. 
Tablo 3.

Kız ve Erkek Çocuk Figürlerin Birlikte Gösterildikleri Kişiler

\begin{tabular}{|c|c|c|c|c|c|c|c|c|c|c|c|}
\hline \multirow{2}{*}{ 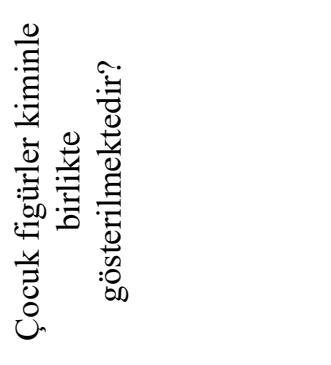 } & \multicolumn{4}{|c|}{$\mathrm{KIZ}$} & \multirow{2}{*}{ 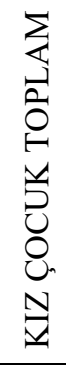 } & \multicolumn{4}{|c|}{ ERKEK } & \multirow{2}{*}{ 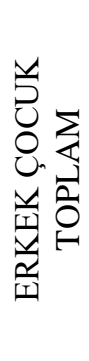 } & \multirow{2}{*}{ 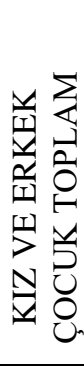 } \\
\hline & 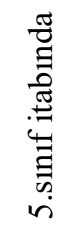 & 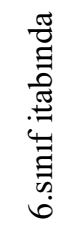 & 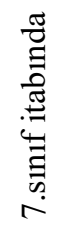 & 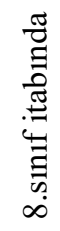 & & 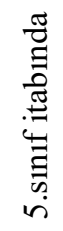 & 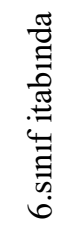 & 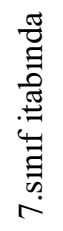 & 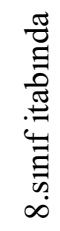 & & \\
\hline Tek başına & 1 & 7 & 4 & 1 & 13 & 4 & 2 & 0 & 5 & 11 & 24 \\
\hline Çocuklarla & 6 & 7 & 4 & 5 & 22 & 4 & 1 & 4 & 9 & 30 & 52 \\
\hline Yetişkinlerle & 0 & 1 & 0 & 0 & 1 & 1 & 2 & 0 & 9 & 12 & 13 \\
\hline Çocuk ve Yetişkinlerle & 2 & 2 & 3 & 6 & 13 & 3 & 2 & 1 & 6 & 12 & 25 \\
\hline Ailesi ile & 1 & 5 & 1 & 1 & 8 & 1 & 3 & 1 & 1 & 6 & 14 \\
\hline Kalabalık ile & 1 & 2 & 0 & 1 & 4 & 1 & 3 & 1 & 1 & 6 & 10 \\
\hline Toplam & 11 & 24 & 12 & 14 & 61 & 14 & 13 & 7 & 31 & 77 & 138 \\
\hline
\end{tabular}

Çalışmanın birinci kategorisi ile bağlantılı olarak ders kitaplarındaki "çocuk figürlerin kimlerle birlikte gösterildikleri" de incelenmiş ve sonuçta erkek çocukların ve kız çocukların sırasıyla yine en çok çocuklarla resmedildikleri tespit edilmiştir.

Esen Severge (1998) de yaptığı çalışmada hem kız ve hem erkek çocuklarının en fazla çocuklarla resmedildiğini saptamıştır. Mevcut çalışmada da benzer bir sonuç elde edilmiş olup hem kız ve hem erkek çocuklar en fazla yine çocuklarla resmedilmiştir. Mevcut çalışma ile Esen Severge'nin 1998 yılında yaptığı çalışmanın bulgularının örtüştüğü gözlenmiştir. Kız veya erkek olsun bütün çocukların en çok yine çocuklarla resmedilmesi, günlerinin büyük bir bölümünü okulda ve arkadaşlarıyla geçirmelerinin sonucu olarak görülmüş ve dolayısıyla çocukların akranlarıyla resmedilmelerinin doğal olduğu düşünülmüştür (Esen Severge, 1998).

Dikkat çekici durumlardan bir diğeri de ailesi ile resmedilme durumu incelendiğinde kız çocukların oranının daha yüksek olmasıdır. Çünkü çocuklar büyüdüklerinde eğer erkekse özgür olabileceği, yalnız dolaşabileceği, çeşitli eylemlerde bulunabileceği ve bağımsız hareket edebileceği; fakat kız çocuklarının yalnız dolaşmasının uygun görülmeyeceğine ilişkin toplumsal kalıp yargının burada karşılık bulduğu görülmektedir.

5. sınıf kitabında erkek çocuklarının tek başına, çocuklarla ve yetişkinlerle gösterilme oranı en yüksektir. Yine 5. sınıf kitabında kız çocuklarının ise en çok tek başına ve yetişkinlerle resmedilmesi söz konusudur. $\mathrm{Bu}$ durum 5. Sinıf kitaplarında kızlarda bağımsız olma düşüncesini temsil etmesi açısından umut verici gelişme olarak düşünülebilir.

İncelemeye 6. sinıflarla devam ettiğimizde hem kız hem erkek çocukların en çok tek başına ve yetişkinlerle resmedildiği görülmektedir. Burada dikkat çekici nokta 45 resimden 36 tanesinde yani \%80'inde erkek çocukların tek başına ve yetişkinlerle resmedildiğidir. Erkek çocuklar sadece 9 resimde kalabalıkla, ailesi ile, çocuklarla, çocuk ve yetişkinlerle resmedilmişlerdir. Kızlarda aynı durum incelendiğinde ise oran yaklaşık \%67'dir.

7. sınıfa ait kitaplarda erkekler en çok tek başına, kızlar ise çocuk ve yetişkinlerle birlikte resmedilmiştir. 8. Sınıf kitapları incelendiğinde ise erkekler tek başına en çok resmedilirken kızlarda tek başına resmedilme ile çocuk ve yetişkinlerle resmedilme oranı eşit ve en yüksek çıkmıştır.

Sınıf düzeylerine göre incelendiğinde 5, 6 ve 7 .sınıf kitaplarına oranla, 8. sinıf kitabında daha fazla erkek görseli bulunduğu görülmektedir. Yavuzer'e (2001) göre ergenlik dönemi, biyolojik, psikolojik, zihinsel ve sosyal açıdan bir gelişme ve olgunlaşmanın yer aldığ çocukluktan erişkinliğe geçiş dönemidir. Bu dönem ülkemizde kızlarda ortalama olarak 10-12, 
erkeklerde 12-14 yaşları arasında başlar. Ergenliğin başladığı bu yaşlar Türkiye'de tam da ortaokul yıllarına denk gelmektedir. Bu nedenle bu dönemde öğrenciler çocukluktan gençliğe geçiş aşamasında ve kendi kimliklerini bulma yolunda arayış içerisindedirler. Zamanlarının çoğunu okulda, derslerde geçirmektedirler ve ders süresince de kullandıkları ders kitaplarının da yardımı ile farkına varmadan cinsiyetlerine ait kimlik özellikleri kazanmaktadırlar. Yani 8.sınıf kitaplarında daha fazla erkek görseli resmedilerek onların resmedildikleri mekân, eylem ve kimlerle resmedildikleri gibi durumlar rol ve kimlik arayışı içerisinde olan ergenlik çağındaki çocuklara kitaplar yoluyla iletilmiş olmaktadır.

Tablo 4'te yetişkin figürlerin birlikte gösterildikleri kişilerin cinsiyetine yer verilmiştir.

Tablo 4.

Yetişkin Figürlerin Birlikte Gösterildikleri Kişilerin Cinsiyeti

\begin{tabular}{lccc}
\hline $\begin{array}{l}\text { Yetişkin Figürlerin Birlikte Gösterildikleri } \\
\text { Kişilerin Cinsiyeti }\end{array}$ & Erkeklerle & Kadınlarla & Toplam \\
\hline Kadın & 29 & 15 & 44 \\
Erkek & 35 & 25 & 60 \\
\hline Toplam & 64 & 40 & 104 \\
\hline
\end{tabular}

Tablo 5'te ise çocuk figürlerin birlikte gösterildikleri kişilerin cinsiyetine ait bulgular yer almaktadır.

Tablo 5.

Çocuk Figürlerin Birlikte Gösterildikleri Kişilerin Cinsiyeti

\begin{tabular}{|c|c|c|c|c|c|c|c|c|c|c|c|}
\hline \multirow[b]{2}{*}{ 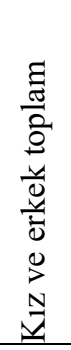 } & \multicolumn{5}{|c|}{ Erkek çocuk } & \multicolumn{5}{|c|}{ Kız çocuk } & \multirow[b]{2}{*}{ 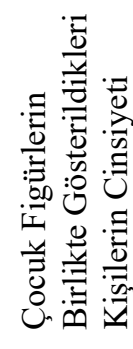 } \\
\hline & 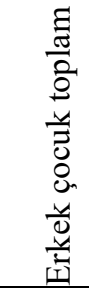 & 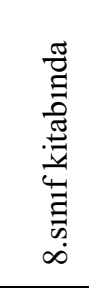 & 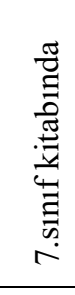 & 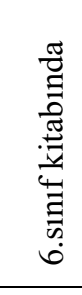 & 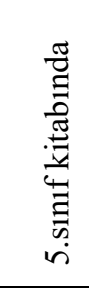 & 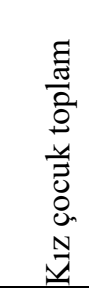 & 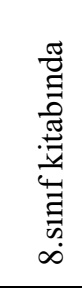 & 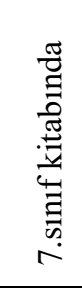 & 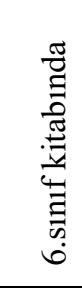 & 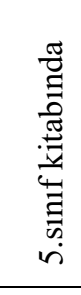 & \\
\hline 75 & 41 & 12 & 4 & 14 & 11 & 34 & 8 & 6 & 11 & 9 & Kadın \\
\hline 85 & 42 & 13 & 4 & 13 & 12 & 43 & 12 & 4 & 17 & 10 & Erkek \\
\hline 160 & 83 & 25 & 8 & 27 & 25 & 77 & 20 & 0 & 28 & 19 & Toplam \\
\hline
\end{tabular}

"Yetişkin figürler ile kız ve erkek çocuk figürlerinin birlikte gösterildikleri kişilerin cinsiyetleri" incelendiğinde kız çocukların hemcinsleriyle resmedilme oranının erkeklerin hemcinsleriyle resmedilme oranından daha düşük olduğu tespit edilmiştir. Yine kitaplardaki görsellerde hem yetişkin kadınların ve hem de yetişkin erkeklerin daha çok erkeklerle resmedildiği görülmüştür.

Ders kitaplarında temsil edilme oranları açısından düşünüldüğünde erkeklerin lehine bir durumu ortaya çıkartmaktadır. Araştırmanın bu bulguları; Gümüşoğlu (1994) tarafindan yapılan "1928'den 1994'e Ders Kitaplarında Cinsiyetçilik"; Demirel (2010) tarafindan yapılan 'sosyal bilgiler ders kitaplarında cinsiyet'; Asan'ın (2006), "Ders Kitaplarında Cinsiyetçilik ve Öğretmenlerin Cinsiyetçilik Algılarının Saptanması"; Çubukçu ve Sivaslıgil'in (2007), "7. Sınıf İngilizce Ders Kitaplarında Cinsiyet Kavramı"; Can (2009), "Tarih Ders Kitaplarında Kadının Görünen Yüzü"; Weitzman, Eiffel ve arkadaşlarının (1987), "Sex-Role Socialization in Picture Booksfor Preschool Children”; Zinec (2000) tarafından, Montenegro'da gerçekleştirilen projeler kapsamında yapılan, "Textbook Analysis (Ders Kitabı Analizleri)" adlı araştırmaların, ders 
kitaplarında kadınların görünmez kılınarak, erkeklerin öncelendiğine yönelik bulgularıyla örtüşmektedir.

Üçüncü kategori altında 'Yetişkin kadın ve erkek figürlerin hangi eylemler içerisinde gösterildikleri’ incelenmiştir. Tablo 6 bu doğrultuda hazırlanmıştır.

Tablo 6.

Yetişkin Figürler Gösterildikleri Eylemlere İlişkin Dağılım

\begin{tabular}{cccl}
\hline &
\end{tabular}

$\mathrm{Bu}$ kategori altındaki bulgular incelenirken yetişkin erkek figürlerin eve yönelik herhangi bir eylem içerisinde resmedilmediği gözlemlenmiştir. Bu durum cinsiyete dayalı toplumsal işbölümünün ders kitaplarına bir yansıması olarak düşünülmektedir. Gök’ün (1994) de belirttiği gibi, eğitim sürecinde toplumsal işbölümünün konumları için bireyler seçilir ve yetiştirilir; eğitim yoluyla sınıflaşmanın ömrü uzatılır ve bu da bir bakıma toplumsal işbölümünün meşru, doğal ve hatta kaçınılmaz olduğu görüşünün kuşaklar arasında intikal ettirilmesini sağlar. "Yani eğitim, toplumsal ve siyasal sistemin meşru, gerekli ve zorunlu saydığı öğeleri (insan gücü, ideolojik ve düşünsel yapılar, inanç sistemleri, politik oluşumlar vb.) yeniden üreten bir kurum rolü oynar" (İnal, 2004). O halde müfredat, ders kitapları, eğitsel materyaller ve dersler, iktidar gruplarının değer ve çıkarlarıyla uyumlu olan eğitsel hedef, konu ve öğrenme stratejilerince yönlendirilir (Van Dijk, 1994).

Ders kitaplarında erkekler daha çeşitli eylemler içerisinde bulunmaktadır. Bu eylemler de daha çok işe yönelik eylemlerdir. Kadınlar ise çoğunlukla eve yönelik eylemlerde (yemek yapmak, temizlik yapmak, çocuğa bakmak vb.) karşımıza çıkmaktadır. Bu sonuç da yine Güney'in (2016) ve Kalaycı'nın (2015) çalışmalarıyla paralellik göstermektedir. Gümüşoğlu'nun (2008) da belirttiği gibi kadınların daha çok özel alana erkeklerin ise kamusal alana yönlendirilmesinin ders kitapları aracılığıyla sürdürüldügü görülmektedir.

Kitaplardaki örneklerde ve resimlerde boya yapma eylemi sık karşıllaşılan bir eylem olmuştur. Boya yapan erkeklerin de resmedilme sayısının çok olduğu görülmektedir. Boya 
yapmak sadece erkeklere özgü bir iş gibi kitapların hiçbir seviyesinde boya yapan kadın gösterilmemiştir. Bu durum boya yapmak vb. gibi güç gerektiren işlerin erkeğe özgü olması ile ilgili bir vurgu olarak düşünülmüştür. Erkek güçlüdür; kadın ise güçsüzdür, kendi başına bu tür işleri yapamaz. Bu işlerin yapılması için erkeğe ihtiyaç vardır. Güney (2016) de çalışmasında erkek görsellerin ortaokul ders kitaplarda daha dominant ve güçlü karakterler şeklinde yer aldığını tespit etmiştir. Tablo 7'de çocuk figürlerin gösterildikleri eylemlere ilişkin dağılım yer almaktadır.

Tablo 7.

Çocuk Figürlerin Gösterildikleri Eylemlere İlişkin Dağılım

\begin{tabular}{|c|c|c|c|}
\hline 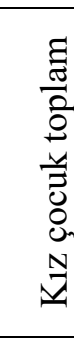 & 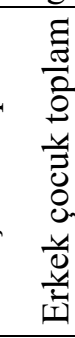 & 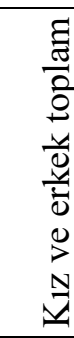 & Çocuk Figürler Hangi Eylem İçinde Gösterilmektedir? \\
\hline 12 & 18 & 30 & $\begin{array}{l}\text { Okula/Öğrenmeye yönelik eylem (örneğin sınıf içi etkinlikler, ödev yapmak, } \\
\text { ders çalışmak, demokrasi eğitiminde oy kullanmak, sınav olmak, soru } \\
\text { çözmek, deney yapmak vb. }\end{array}$ \\
\hline 9 & 11 & 20 & $\begin{array}{l}\text { Oyun/ Eğlence (örneğin top oynamak, çocuk oyunları oynamak, bisiklete } \\
\text { binmek, çilek toplamak, havaya taş atmak, ip atlamak vb.) }\end{array}$ \\
\hline 13 & 12 & 25 & $\begin{array}{l}\text { Kültür/Sanat (örneğin kitap okumak, tiyatroya gitmek, sinemaya gitmek, şark1 } \\
\text { söylemek, müzik aleti çalmak, fotoğraf çekmek, resim yapmak vb.) }\end{array}$ \\
\hline 10 & 9 & 19 & Spor (örneğin koşmak, yüzmek, yürümek vb.) \\
\hline 7 & 6 & 13 & $\begin{array}{l}\text { Sosyal(örneğin piknik yapmak, doğum günü partisine katılmak, fotoğraf } \\
\text { çektirmek, alışveriş yapmak, el öpmek, } 23 \text { Nisan tören provas1 yapmak vb.) }\end{array}$ \\
\hline 1 & 1 & 2 & Evdeki eylemler (yemek yemek, su içmek, televizyon izlemek vb. \\
\hline 4 & 5 & 9 & Kişisel eylemler (örneğin dişini furçalamak, uyumak vb.) \\
\hline 8 & 9 & 17 & Eylemsiz (örneğin ayakta durmak vb.) \\
\hline
\end{tabular}

Çocuk figürlerinin hangi eylemler içerisinde resmedildikleri konusunda ders kitapları incelendiğinde cinsiyet açısından çocuk sayılarının neredeyse eşit olarak resmedildiği görülmüştür. Kız çocuk figürleri sırasıyla en çok kültür/sanata yönelik, okula/öğrenmeye yönelik, spora, oyun/eğlenceye yönelik eylemler içerisinde, sonra da eylemsiz ve sosyal, kişisel eylemler içerisinde ve son olarak da evdeki eylemler içerisinde resmedilmektedir. Erkek çocuklar ise en çok okula/öğrenmeye yönelik eylemler, kültür/sanata yönelik eylemler, oyun/eğlenceye yönelik eylemler, spora yönelik eylemler, eylemsiz, sosyal eylemler, kişisel eylemler ve evdeki eylemler içerisinde resmedilmektedir. Genel olarak kız ve erkek çocuk figürlerin eylem türleri ve bu eylemlerde bulunma sıklıkları açısından benzerlikler söz konusudur. Fakat en büyük farkın eve yönelik eylemlerde olduğu, erkek çocukların kızlara oranla eve yönelik eylemlerde daha az sayıda resmedildikleri görülmüştür. Tablo 8'de yetişkin figürlerin gösterildiği mekânlara yer verilmiştir.

"Yetişkin figürlerin gösterildikleri mekânlar" incelendiğinde diğer tüm kategorilerde olduğu gibi erkek görsel sayısı kadın görsel sayısının neredeyse iki katı kadardır. Ayrıca kadınlarda işte olma durumu 3. sırada iken erkeklerde ise 1.sırada yer almaktadır. Kadınlar işte resmedilmek yerine evde daha çok resmedilmişlerdir. Bu görünüm ise ilgili alanyazında karşılaşılan benzer bulguları destekler niteliktedir. 
Tablo 8.

Yetişkin Figürlerin Gösterildiği Mekânlar

\begin{tabular}{|c|c|c|c|}
\hline 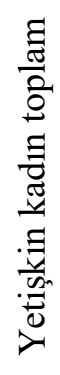 & 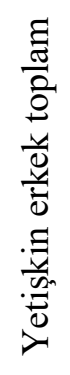 & 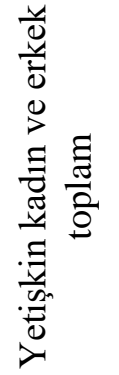 & Yetişkin Figürler Hangi Mekânda Gösterilmektedir? \\
\hline 11 & 7 & 18 & Ev ve Ev Çevresi (evde) \\
\hline 4 & 6 & 10 & Okul ve okul çevresi (örneğin okulda, okulun önünde vb.) \\
\hline 15 & 32 & 47 & $\begin{array}{l}\text { Dış mekân (örneğin dışarıda/sokakta, metroda, piknik alanında, kitap } \\
\text { fuarında, otobüste, stadyumda, bilgisayar mağazasında, resim atölyesinde } \\
\text { veya sergide, garajda, tiyatroda, oyuncak, mağazasında, sinemada, parkta, } \\
\text { markette, alışverişte, benzincide, denizde (dalgıç), dağda, (dağcı), sporda, } \\
\text { dışarıda(ev bakıyorlar), doğada izci, dışarıda vb. }\end{array}$ \\
\hline 2 & 2 & 4 & Kurum ve kuruluş (Örneğin bankada) \\
\hline 9 & 32 & 41 & $\begin{array}{l}\text { İşyerinde (örneğin borsada, madende, bankada, sahnede, firında, tarlada, } \\
\text { pazarda, manavda vb.) }\end{array}$ \\
\hline 41 & 79 & 120 & Toplam \\
\hline
\end{tabular}
almaktadir.

"Çocuk figürlerin hangi mekânlar"da resmedildiklerine ait bilgiler tablo 9 da yer

Tablo 9.

Çocuk Figürlerin Gösterildiği Mekânlara İlişkin Dağılım

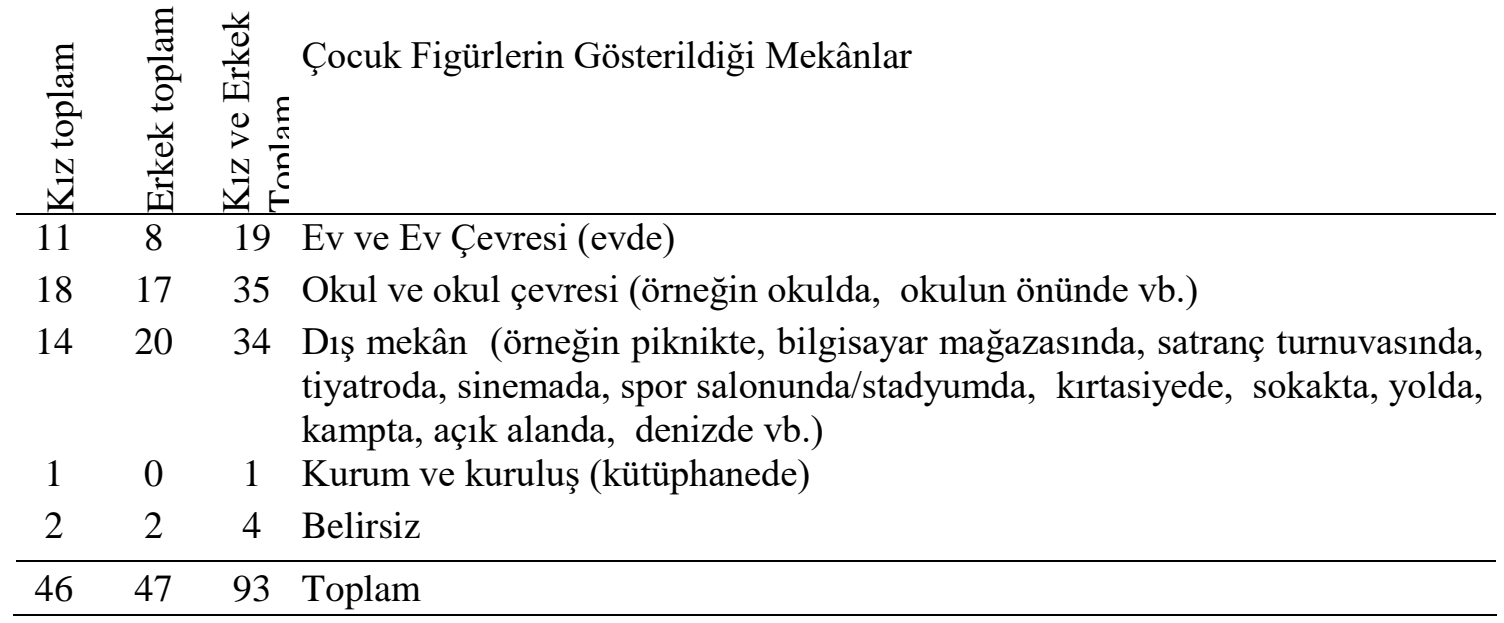

Çocuk figürlerinin hangi mekânlarda resmedildikleri incelendiğinde ise kız ve erkek çocuk figürlerinin resmedildikleri mekân sayısının hemen hemen eşit olduğu görülmektedir.

Kız çocuklarının 46, erkek çocuklarının ise 47 mekânda resmedildikleri görülmüştür. Sayıların birbirine çok yakın olduğu belirlenmiş olmasına rağmen erkek çocuklarının daha çok dış mekânlarda, kız çocuklarının ise en çok okulda resmedilmesi dikkat çekmektedir. Böylece 
bu bulguyla kızların dış mekânda olmasının uygun görülmediği düşüncesinin ders kitaplarında dahi desteklendiği görülmüştür.

Kitaplarda yer alan toplumsal cinsiyete ilişkin kalıp yargılardan bir diğeri ise meslek seçiminde karşımıza çıkmaktadır. Tablo 10'da bu durumu ayrıntılı olarak görmek mümkündür. Ders kitapları incelenirken daha önce yapılan araştırmalarda meslekler kategorisinin eksikliği fark edilmiş ve kitapların bu açıdan da incelenmesinin faydalı olabileceği düşünülmüştür. Bölüm hazırlanırken birçok kaynakta çok çeşitli meslek sınıflandırmalarına rastlanmıştır. Bunlardan en yaygın olanı 2014 yılında Türkiye İstatistik Kurumu (TÜIK) tarafindan hazırlanan ISCO 08 adlı uluslararası standart meslek sinıflamasıdır.

$\mathrm{Bu}$ bölümde sadece ortaokul matematik kitaplarında yer alan görsellerde yer alan mesleklere yer verilmiştir. Tespit edilen bu meslekler ile ISCO 08'de yer alan kategoriler ilişkilendirilerek tablo 10 'da sunulmuştur.

Tablo 10.

Ortaokul Matematik Ders Kitaplarında Yer Alan Görsel Öğelerde Yetişkin Figürlerin Olası Meslekleri

\begin{tabular}{|c|c|c|c|}
\hline 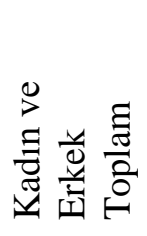 & 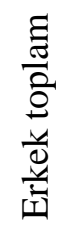 & 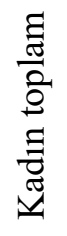 & Yetişkin Figürlerin Olası Meslekleri \\
\hline 21 & 13 & 8 & $\begin{array}{l}\text { Profesyonel meslek mensupları (Örneğin öğretmen, doktor, } \\
\text { araştırmac1, borsacı, mühendis, ressam, tiyatro oyuncusu) }\end{array}$ \\
\hline 1 & 1 & 0 & Teknisyenler, teknikerler (Örneğin kameraman) \\
\hline 21 & 16 & 5 & $\begin{array}{l}\text { Yardımcı profesyonel meslek mensupları (Örneğin pilot, emlakçı, } \\
\text { spiker, sporcu, izci lideri, dağc1, antrenör) }\end{array}$ \\
\hline 7 & 5 & 2 & $\begin{array}{l}\text { Hizmet ve satış elemanları (Örneğin host, pompacı, bankacı, araç satış } \\
\text { danışmanı, garson, aşçı) }\end{array}$ \\
\hline 12 & 12 & 0 & $\begin{array}{l}\text { Sanatkârlar ve ilgili işlerde çalışanlar (Örneğin marangoz, terzi, } \\
\text { tamirci, boyac1) }\end{array}$ \\
\hline 3 & 3 & 0 & $\begin{array}{l}\text { Tesis ve makine operatörleri ve montajcıları (Örneğin iş makinesi } \\
\text { operatörü, madenci) }\end{array}$ \\
\hline 24 & 20 & 4 & $\begin{array}{l}\text { Nitelik gerektirmeyen işlerde çalışanlar (Örneğin kırtasiyeci, fayans } \\
\text { ustası, pazarcı, bilgisayar mağazasında çalışan, manav, firınc1, } \\
\text { apartman görevlisi, izci, panayırda baloncu, satıc1, işçi, çiftçi) }\end{array}$ \\
\hline 1 & 1 & 0 & Diğer (Örneğin hakem) \\
\hline 90 & 71 & 19 & Toplam \\
\hline
\end{tabular}

Mevcut çalışmada kadın ve erkek figürlerin mesleksel anlamda resmedilme sayısındaki büyük fark dikkat çekmektedir. Bu konuda kadınlara sadece 19 resimde yer verilirken buna karş1lı erkeklere ise 71 resimde yer verildiği açıkça görülmektedir.

"Yetişkin kadın ve erkek figürlerinin olası meslekleri" incelendiğinde kadın figürlerin sırasıyla profesyonel meslek, yardımc1 profesyonel meslek, nitelik gerektirmeyen işler, hizmet ve satış elemanları, teknisyen/tekniker erkeklerin ise sırasıyla nitelik gerektirmeyen işler, yardımcı profesyonel meslek, profesyonel meslek, sanatkâr, hizmet ve satış elemanları, tesis ve makine operatörü, diğer meslek gruplarında resmedildikleri gözlenmiştir.

Profesyonel meslekler (öğretmen, doktor, araştırmac1, borsac1, mühendis, ressam, tiyatro oyuncusu/aktör) kendi içinde incelendiğinde ise 13 erkeğe karşıllk sekiz kadın tespit edilmiştir. $\mathrm{Bu}$ durum erkeklerin profesyonel olarak iş hayatında kadınlardan daha çok yer aldığını göstermektedir. Güney (2016) de 2015-2016 eğitim öğretim yılına ait üç ortaokul Türkçe ders kitabını incelemiş ve yaptığı çalışmasında erkeklerin kadınlara oranla profesyonel 
mesleklerde daha fazla gösterildiğini belirtmiştir.

Teknisyenlik mesleği grubunda bir erkeğe (kameraman figüründe) yer verildiği fakat hiç kadının olmadığı görülmüştür. Yine yardımcı profesyonel meslek (pilot, emlakçı, spiker, sporcu, izci lideri, dağc1, antrenör) grubunda da 16 erkeğe karşılık beş kadın figür olduğu; bu grupta yer alan erkeklerin sayısının kadınların sayısının üç katından daha fazla olduğu görülmüştür. Hizmet ve satış elemanları kategorisinde de (host, pompacı, bankacı, araç satış danışmanı, garson, aşçı) iki kadına karşı1ık beş erkeğe yer verildiği görülmüştür. Sanatkârlar ve ilgili işlerde çalışanlar (marangoz, terzi, tamirci, boyacı) kategorisinde hiç kadın gösterilmediği fakat on iki erkek figüre yer verildiği görülmüsstür. Buradan hareketle marangoz, tamirci, terzi, boyacı vb. gibi mesleklerde hep erkeklerin temsil edilmesi ve "bu meslekler erkeklere göredir" algısının kitaplar aracılığıyla devam ettirilmesi durumu dikkat çekici bir bulgudur.

Türkiye İstatistik Kurumu'nda (TÜİK), (2014) yayınlanan Uluslararası Standart Meslek Sınıflaması- ISCO 08'in 8. kategorisi olan tesis ve makine operatörleri ve montajcıları (iş makinesi operatörü, madenci) sınıfında üç erkeğin bulunduğu ve kadınların bu kategoride yer almadığ1 görülmüştür. Benzer şekilde nitelik gerektirmeyen işlerde çalışanlar (kırtasiyeci, fayans ustası, pazarcı, bilgisayar mağazasında çalışan, manav, fırıncı, apartman görevlisi, izci, panayırda baloncu, satıcı, işçi, çiftçi) sınıfında da beş kadına karşılık yirmi erkek olması; erkek figürlerin sayısının kadın figürlerin sayısının tam dört katı olması diğer sonuçlarla paralellik göstermektedir. "Diğer" sınıfinda da bir tane erkek hakem figürüne rastlanmıştır.

Ünal'ın (1994) çalışmasına göre mesleki açıdan bir erkek, çiçekçi olmaktan çok kamyon şoförü olmayı; meslek dışında ise dansa gitmekten çok futbol maçına gitmeyi istemektedir. Aynı çalışmada erkeklerin daha çok macera, makine ve ilimle, kadınların ev işleri, sanat vb. mesleklerle ilgili oldukları; aynı zamanda yarışmacı, atılgan, sert yapılı oldukları tespit edilirken, kadınların ise daha heyecanlı, daha duyarlı oldukları tespit edilmiştir. Bu açıdan mevcut çalışmada da Ünal'ın (1994) bu çalışmasını destekleyen sonuçların ortaya çıktığı görülmüştür.

İncelenen kitaplarda erkeklerin ise sırasıyla sporcu, öğretmen, antrenör, pazarc1, boyac1, satıcı, çiftçi, spiker, terzi, marangoz, madenci, kırtasiyeci ve tiyatrocu oldukları görülmektedir Kitaplarda kadın figürlerin sadece birer kez gösterildiği işler ise şöyle sıralanmaktadır: satıcı, sporcu, spiker, pazarc1, dağc1, çiftçi, doktor ve iş̧̧i kadın görsellerine rastlanmıştır. Erkeklerde bir kez resmedilmenin ise fırıncı, host, bilgisayar mağazasında çalışan, ressam, fayans ustası, hakem, garson, manav, pompacı, araştırmacı, araç satış danışmanı, dağc1, apartman görevlisi, usta, borsacı, antrenör, aşçı, emlakçı, izci, baloncu, mühendis, pilot, iş makinası operatörü ve kameraman olarak yapıldığı görülmektedir. Sonuç olarak erkeklerde meslek alanlarının kadınlara oranla çok daha geniş temsil edildiği görülmektedir.

Genel olarak yapılan çalışmalarda (Çubukçu ve Sivaslıgil, 2007; MacNaughton, 2006; Vatandaş, 2011; Yaylı, Kitiş ve Çınar, 2014; Yurtsever, 2011) aşağıda da ayrıntılı olarak belirtileceği gibi, erkeklerin kadınlara oranla resmedilme oranının fark edilir düzeyde daha yüksek olduğu görülmüş olup, ders kitaplarında kadınların edilgen, pasif, duygusal özellikleri ön plana çıkarılırken; erkeklerin ise daha aktif, güçlü, korumacı özellikleri vurgulanmıştır. Erkek sokakta, işte ve dışarıda herhangi bir yerlerde resmedilirken kadın ise çoğunlukla evde ev işleriyle meşgul iken görülmektedir. Yani yemek yaparken, sofra kurarken, temizlik yaparken vb. durumlarda resmedilmiştir. Yine kadınların kitaplar boyu çocuklarla ilgilenme konusundaki resimleri dikkat çekmektedir. Tüm bu çalışmalar dünyada halen cinsiyet kalıpyargılarının günümüzde kitaplar yoluyla yeniden üretilip aktarılmaya devam ettiğini göstermektedir.

MacNaughton'a (2006) göre kadın veya erkekler rollerini öğrenip kendilerinden beklenildiği gibi davranmaktadırlar. Örneğin kadınlar anneleri veya kadın öğretmenleri veya hemşireler gibi bakım işlerine yönelmekte, erkekler ise daha çok ev dışındaki işlerde faaliyet göstermektedirler. Mevcut çalışmada da benzer bulgular elde edilmiş olup kadınlar çok az sayıda görselde bir iş yaparken gösterilmektedir. Yaylı, Kitiş ve Çınar'ın (2014) elde ettiği sonuçların da mevcut çalışmayla benzerlik gösterdiği görülmektedir. 
İncelenen ortaokul matematik ders kitaplarında yer alan çocuk görsellerinden çoğunun erkek çocuk figürü olması, kız çocuklarının incelenen ders kitapları açısından ikinci planda temsil edildiğini göstermektedir. Yetişkin erkek ve kadın görsellerinde de durum benzerdir. Çubukçu ve Sivaslıgil'in (2007) Milli Eğitim Bakanlığı'nca hazırlanan ve devlet okullarında okutulan İngilizce 7. sinıf Let's Speak English adlı ders kitabı metinlerinin incelemesi sonucunda erkeklerin kadınlara göre daha sıklıkla temsil edildikleri tespit edilmiştir. Çubukçu ve Sivaslıgil'in bu çalışmasında bulunan bu sonuç mevcut çalışmanın sonucuyla uyumluluk göstermektedir.

Yurtsever (2011) de çalışmasında ilköğretim ikinci kademe öğretmenlerin toplumsal cinsiyet kalıp yargılarına sahip olduğunu ve bu doğrultuda öğrencilerine cinsiyetlerine göre farklı tutum ve davranışlar geliştirdiklerini ortaya koymuştur.

Vatandaş (2011), 15 yaş üstü 197 yerleşim biriminde 3454 kişiye uyguladığı ankette Türkiye'de insanların toplumsal cinsiyet bağlamında sahip olduğu düşünce ve tutumlarının neler olduğunu, bu düşünce ve tutumların cinsiyet rollerinin şekillenmesine ve bireylerin cinsiyet temelinde ayrışmasına nasıl yansıdığını tespit etmeyi amaçlamıştır. Vatandaş "Toplumsal Cinsiyet ve Cinsiyet Rollerinin Algılanışı" başlıklı bu çalışması sonucunda toplumsal cinsiyetin getirdiği rol ayrımın sahip olunan düşünce ve tutumlar açısından devam ettirildiğini ve bu düşünce ve tutumların cinsiyet rollerinin şekillenmesine ve bireylerin cinsiyet temelinde ayrışmasına sebep olduğunu saptamıştır. Ev içindeki işbölümü ve ev dışında iş hayatındaki kadın ve erkeğe atfedilen rollerin Vatandaşın yaptığı çalışmanın üzerinden 10 yıl geçmiş olmasına rağmen hala devam ettiği matematik kitaplarının incelendiği mevcut çalışmada da açık bir şekilde görmek mümkündür. Vatandaşın çalışmasındaki sonuçla bu çalışmanın sonucunun kadın ve erkek rol ayrışması bakımından örtüştüğü ve hem bireylerin tutumlarına hem de müfredata yansıdığı söylenebilir.

Toplumsal cinsiyet konusu çerçevesinde cinsiyet eşitsizliğini ortadan kaldırmaya yönelik dünya çapında birçok çalışma yapılmaktadır. Örneğin 1985 yılında Nairobi'de 3. Dünya Kadın Konferansı ve 1995 yılında Pekin'de 4. Dünya Kadın Konferansı yapılmıştır. Bu konferansta kadınlara yönelik cinsiyet ayırımcılığı yapıldığı ve ayrıca eğitim materyallerinde de cinsiyet ayrımcılığının olduğu tespit edilmiştir. Bunun giderilmesi için hükümetlerden gerekli önlemlerin alınması istenmiştir. Özellikle 1980'de Kopenhang'da toplanan ikinci Dünya Kadın Konferans1 sonucunda 1981 yılından itibaren Unesco'nun desteğinde çeşitli ülkelerde eğitim materyallerinde cinsiyet ayrımcılığını konu alan araştırmalar yapılımıştır. Ayrıca kitaplardaki cinsiyet ayrımcılığının ortadan kaldırılması için bazı kılavuzlar da geliştirilmiştir.

Türkiye'de de Milli Eğitim Bakanlığı'nın (MEB) da konuyla ilgili çalışmalar yaptığı görülmektedir. Örneğin Eğitimde Toplumsal Cinsiyet Eşitliğinin Geliştirilmesi Projesi (ETCEP) yapılmıştır ve proje halen devam etmektedir. Devam eden bu projede, pilot olarak belirlenen illerde, projenin amaçlarına yönelik olarak birçok faaliyet gerçekleştirilmiştir ve halen gerçekleştirilmektedir.

Dünya Ekonomik Platformu'nun 2017 Küresel Toplumsal Cinsiyet Uçurumu Raporu'na (2017) göre Türkiye'nin küresel cinsiyet eşitliği puanının yıllar geçtikçe daha da gerilediği görülmektedir. 2014'te 142 ülke arasında 125. sirada yer alan Türkiye, 2015'te 145 ülke arasında 130. sirada ve son olarak da $2017^{\prime}$ 'de ise 144 ülke arasindan 131. sirada yer almaktadır. Toplumsal cinsiyet kalıpyargılarına göre yetişen kadın kendi çocuklarını da aynı yargılarla yetiştirmektedir (Metin, 2011). Kadınların rollerini içselleştirdiğini, daha sonra bunu davranışa dökerek dışsallaştırdığını tüm bu toplumsal düzenin nesneleri haline geldiklerini belirten Metin (2011) bu döngünün süreklilik arz ettiğini ifade etmektedir. MacNaughton (2006) da aynı şekilde kadınlar için eşitsizliklerin siyaset, çalışma hayatı, eğitim gibi çok önemli kamusal alanlarda ömür boyu devam ettiğini belirtmektedir.

\section{Sonuç}

Ortaokul matematik ders kitaplarında toplumsal cinsiyetin incelendiği bu araştırmadan elde edilen sonuçların en belirgini bütün kitaplarda erkek figürlere ait görsel sayısının yetişkin ya da çocuk olsun kadın figürlerden daha fazla olmasıdır. Diğer bir durum ise genel olarak her iki 
cinsiyette de yetişkinlerin en fazla tek başına resmedilmelerine rağmen yetişkin erkeklerin tek başına resmedilme oranının yetişkin kadınların resmedilme oranının iki katından fazla olmasıdır. Bu sonuç erkeklerin tek başına olabilme ya da bağımsız hareket edebilme cinsiyet kalıpyargısına işaret etmesi nedeni ile önem taşımaktadır. İncelemede 5, 6 ve 7.sınıf kitaplarına oranla, 8. sınıf kitabında daha fazla erkek görseli bulunduğu görülmektedir.

Dikkat çekici sonuçlardan bir diğeri de ailesi ile resmedilme durumu incelendiğinde kız çocukların oranının daha yüksek olmasıdır. Öte yandan 'çocuk figürlerin birlikte gösterildikleri kişilerin cinsiyeti' incelendiğinde gerek kız çocuk ve gerekse erkek çocuk figürlerinin daha çok yetişkin erkeklerle resmedildikleri ve kız çocukların hemcinsleriyle resmedilme oranının erkeklerin hemcinsleriyle resmedilme oranından daha düşük olduğu ortaya çıkmıştır. Bu durum da erkek figürlerin temsil oranına ilişkin sonuç ile örtüşmektedir.

Mevcut çalışmada karşımıza çıkan bir diğer sonu da yetişkin erkek figürlerin, hiçbir görselde ne çocuğa, ne de eve yönelik herhangi bir eylem içerisinde resmedilmemeleridir.

Ortaokul matematik ders kitaplarındaki görsellerde yetişkin kadın ve erkeklerin eylemleri geleneksel cinsiyet rollerini pekiştirir nitelikte bir farkl1lık göstermektedir. Buna göre genel olarak kadınlar yemek yapmakta, televizyon seyretmekte, spor yapmakta, yürümekte, misafire ikram sunmakta, satış yapmakta, seyahat etmekte, işte çalışmakta, tiyatro izlemekte, tiyatro sahnesinde rol almakta, örgü örmekte, alışveriş yapmakta, vitrine bakmakta, yüzmekte, evde oturmakta, hava durumu sunmakta, evde iş yapmakta, çocukla oynamakta, tarla sürmektedir. Buna karşılık erkekler ise gazete okumakta, televizyon seyretmekte, spor yapmakta, ekmek yapmakta (firınc1), piknik yapmakta, seyahat etmekte, satış yapmakta, garson olarak servis yapmakta, ders anlatmakta, resim yapmakta, fayans döşemekte, işte çalışmakta, tiyatro izlemekte, tiyatro sahnesinde rol almakta, terzi olarak dikiş dikmekte, koroya şeflik yapmakta, boya yapmakta, alışveriş yapmakta, anket yapmakta, benzincide pompacılık yapmakta, yürüyüş yapmakta, hava durumu sunmakta, madende çalışmakta, denize dalmakta, evde oturmakta, çobanlık yapmakta, tarlayı sürmekte, borsada çalışmakta, marangozluk yapmakta, iş makinesi kullanmakta, evde ek iş yapmaktadır.

Kitaplardaki dikkat çekici diğer bir durum ise kadınlar ve erkeklerin boş zamana yönelik eylemleridir. İncelenen ders kitaplarında kadın ve erkeklerin boş zaman eylemlerinin resmedilmesi iki cinsiyete yönelik toplumsal rol tanımlarını temsil etmektedir. Kadınların boş zamana yönelik eylem olarak resmedildiği görsellerde örgü ördüğü, televizyon seyrettiği, spor yaptığı, vitrine baktığı ve yüzdüğü; erkeklerin ise boş zamanlarını gazete okuyarak, spor yaparak, yürüyüş yaparak, televizyon seyrederek ve yüzerek geçirdikleri görülmektedir. Bu bulgudan ortaya çıan diğer bir sonuç ise spor yaparken resmedilme durumudur. Spor yapan erkek 13 iken buna karşılık spor yapan kadın sayısı sadece üç tanedir. Kadınlara öngörülen eylemler içerisinde spor yapmak sınırlı bir durum olarak karşımıza çıkmaktadır.

İncelenen ders kitaplarında kız ve erkek çocukların gösterildikleri eylem türleri de farklılıklar göstermektedir. Örneğin oyun oynayan erkek çocuk sayısının kız sayısından fazla olduğu; dört tane kitap okuyan kız çocuğuna karş11ık bir erkek çocuğunun kitap okuduğu, spor yapan erkek çocuk sayısının kız çocuk sayısından daha fazla olduğu, oy kullanan erkek çocuk iki tane iken kız çocuğun yalnızca bir tane olduğu, el öpen bir kız çocuğunun olduğu fakat erkek çocuğunun el öperken hiç resmedilmediği, müzik aleti çalan iki kız çocuğu var iken müzik aleti çalan erkek çocuk görselinin hiç olmadığı, bisiklete binen, havaya taş atan, uyuyan birer erkek çocuğuna karşılık bu kategorilerde hiç kız çocuğunun olmadığı, çilek toplayan, ip atlayan kız çocuk görselinin bulunduğu ancak bu eylemlerde de erkek görselinin olmadığı tespit edilmiştir.

Ders kitaplarında kadınlar bir iş ortamında resmedilmek yerine daha çok evde ve ev içi alanlarla ilgili etkinliklerde gösterilmişlerdir. Erkeğin çalıştığı, eve gelince dinlendiği, pazara gittiği, maça gittiği olgusu bu imgelerle ortaokul öğrencilerine iletiliyor görünmektedir. Çocuk figürlerin hangi mekânlarda resmedildikleri incelendiğinde de benzer olarak erkek çocuklarının daha çok ev dişı alanlarda resmedilmesi dikkat çekmektedir.

Kitaplarda yer alan toplumsal cinsiyete ilişkin ayrım noktalarından bir diğeri ise mesleki temsillerde karşımıza çıkmaktadır. Profesyonel meslekler incelendiğinde erkeklerin profesyonel olarak iş hayatında kadınlardan daha çok gösterildiği görülmektedir. Mesleksel çeşitlilik 
anlamında resmedilme sayısındaki büyük fark da dikkat çekmektedir. Bu konuda kadınlara sadece 19 resimde yer verilirken buna karşıllk erkeklere ise 71 resimde yer verildiği açıça görülmektedir.

Gümüşoğlu'nun (2008) da belirttiği gibi kadınların daha çok özel alana erkeklerin ise kamusal alana yönlendirilmesinin ders kitapları aracılığıyla sürdürüldüğü görülmektedir. Tüm bu eylemler karşılaştırıldığında ise erkekler daha çeşitli eylemler içerisinde bulunmaktadır. Bu eylemler de daha çok işe ve ev dişı etkinliklere yönelik eylemlerdir. Kadınlar ise çoğunlukla eve yönelik eylemlerde (yemek yapmak, temizlik yapmak, çocuğa bakmak vb.) karşımıza çıkmaktadır. Bu da kadınların ev içinde ve aile ile birlikte tanımlandığı toplumsal cinsiyet kalıp yargilarını destekler niteliktedir.

Sonuç olarak incelenen ortaokul matematik ders kitaplarının cinsiyetçi öğeler içerdiği görülmüsstür. Ders kitapları bu yolla toplumsal cinsiyet tanımlamalarının yeniden üretilmesine katkı sağlamaktadır. Ayrıca ortaokul matematik ders kitaplarında yer alan görsel öğelerde yetişkin kadın ve erkekler ile kız ve erkek çocukların hangi eylemler içerisinde, kimlerle birlikte, hangi mekânlarda ve hangi mesleklerde gösterildikleri toplumsal cinsiyet rolleri ile bağlantılıdır.

\section{Öneriler}

Öncelikle diğer toplumsal eşitsizlik alanlarını da temsil eden cinsiyet eşitsizlikleri ve ayrımcilığının temel bir toplumsal sorun olarak kabul edilmesi ve sonrasında da nasıl önüne geçilebileceği konusunda kurumlar arası işbirliği yapılması, farklı disiplinlerce ortak çalışmaların ortaya konulması ve bunların sonuçlarının değerlendirilerek eğitim politikalarına yansıması önerilebilir. Toplumdaki yapısal formlar eşitsizliğin temel kaynağı olarak görülmekle birlikte okullarda ve diğer eğitim ortamlarında cinsiyetçilik karşıtı eğitimler bu politikaların gündemlerinden birini oluşturabilir. Gelişen dünyada iş yaşamı ve diğer kamusal alanların ortağ 1 olan kadınların ders kitaplarında, eğitim ortamlarında ve okul içi süreçlerdeki temsili ve konumu, kamu politikalarında, özellikle de eğitimle ilgili eşitlikçi politikalarda gözetilmesi gerekmektedir.

Ders kitaplarının, cinsiyet eşitliği konusunda farkındalık yaratma düşüncesi göz önünde bulundurularak hazırlanması amaçlanmalı ve kitap inceleme komisyonlarına da cinsiyet ayrımcılığı konusunda uzman kişilerin görevlendirilmesi sağlanmalıdır. Ders kitapları ve müfredatın eleştirel analizlerinin yapılması ve cinsiyetçi anlayışların eleştirisine dayalı olarak öğrencilerde bilinç uyandırılması bu çalışmanın önerileri arasında yer almaktadır. Ayrıca Milli Eğitim Bakanlığının yürütmekte olduğu cinsiyet eşitliği çalışmalarının sürekliliğinin sağlanması da önem arz etmektedir.

Diğer taraftan ders kitapları ve ders materyallerinin temel kullanıcıları olarak öğretmenlerin de cinsiyet kalıp yargılarının taşıyıcısı olduğu düşünüldüğünde öğretmenlere bu konuda farkındalık kazandırılması fikrine hizmet öncesi ve hizmetiçi eğitim müfredatının temel hedefleri arasinda yer verilmelidir.

$\mathrm{Bu}$ araştırmada ortaokul matematik ders kitaplarındaki görseller toplumsal cinsiyet açısından incelenmiştir. Gelecek araştırmalarda matematik ders kitaplarındaki metinlerin de incelenmesi önerilebilir. Bu çalışmada Esen Severge'nin (1998) ders kitaplarında cinsiyet konusunda kullandığı kategoriler temel alınmış ve meslekler de yeni bir kategori olarak incelenmiştir. Ders kitaplarında cinsiyetçilik ile ilgili olarak bundan sonraki yapılacak olan araştırmalarda, yetişkin ve çocuk figürlerin olası rolleri vb., yeni boyutların eklenmesi önerilebilir. Bununla birlikte ders kitaplarında cinsiyetçilik üzerine yapılan çalışmalar, tüm eğitim kademeleri açısından ve boylamsal çalışmalarla ele alınarak karşılaştırmalı bir biçimde genişletilebilir.

\section{Kaynaklar}

Anderson, D. A. ve Hamilton, M. (2005). Gender role stereotyping of parents in children's picture books: the invisible father. Sex Roles, 52(3-4),145-151.

Asan, H. (2006). Ders kitaplarında cinsiyetçilik ve ögretmenlerin cinsiyet algılarının 
saptanması (Yayımlanmamış yüksek lisans tezi). Kocaeli Üniversitesi Sosyal Bilimler Enstitüsü, Kocaeli.

Aydın, H. (2015). Sosyal bilimlerde nitel araştırma yöntemleri. Konya: Eğitim Yayınevi.

Aydın, N. ve Beşer, Ş. (2013). Ortaokul matematik 7. Sınıf ders kitabı. Ankara: Aydın Yayıncılık ve Eğitim Hizmetleri İnş. Tic. Ve San. A. Ş.

Can, S. (2009). Tarih ders kitaplarında kadının görünen yüzü. Sakarya Üniversitesi uluslararası - disiplinlerarası kadın çalışmaları kongre bildirileri, 2, 300-311.

Çebi, M., Bayar, Ö. ve Çebi, H. (2014). Ortaokul matematik ders kitabı 8. sınıf. Ankara: Dörtel Yayınları.

Çubukçu, H. ve Sivaslıgil P. (2007). 7. sınıf İngilizce ders kitaplarında cinsiyet kavramı. Dil Dergisi, 137(Temmuz-Ağustos-Eylül), 7-19.

Demirel, Ö. (2010). Sosyal bilgiler ders kitaplarında cinsiyet ayrımcıllı̆̆ (Yayımlanmamış yüksek lisans tezi). Dokuz Eylül Üniversitesi Eğitim Bilimleri Enstitüsü Ana Bilim Dalı Sosyal Bilgiler Öğretmenliği Programı, İzmir.

Dökmen, Z. Y. (2004). Toplumsal cinsiyet: Sosyal psikolojik açıklamalar. İstanbul: Sistem Yayınc1lik.

Dünya Ekonomik Platformu (DEF) (2017). Küresel toplumsal cinsiyet uçurumu raporu (2017). Erişim adresi. https://insanhaklarimerkezi.bilgi.edu.tr/tr/news/none-dunyaekonomiforumu-2017-kuresel-cinsiyet-es/

Esen Severge, Y. (1998). Ders kitaplarında cinsiyetçilik: İlkögretim ders kitapları üzerinde yapılmış bir içerik çözümlemesi (Yayımlanmamış yüksek lisans tezi). Ankara Üniversitesi Sosyal Bilimler Enstitüsü, Ankara.

Esen, Y. ve Bağlı, M. T. (2002). İlköğretim ders kitaplarındaki kadın ve erkek resimlerine ilişkin bir inceleme. Ankara Üniversitesi Eğitim Bilimleri Fakültesi Dergisi, 35(1-2), $144-154$.

Francis, B. (2006). The nature of gender. Skelton, C., Francis, B. ve Smulyan, L. (Yay.haz.). The Sage of handbook of gender and education içinde (ss. 7-18). London: Sage Publication

Gök, F. (1994). Türkiye'de eğitim ve kadınlar. Eğitim ve Toplum, 3(Bahar), 5-9.

Gümüş̧oğlu, F. (1994). 1928'den 1994'e ders kitaplarında cinsiyetçilik (Yayımlanmamış yüksek lisans tezi). İ. Ü. Sosyal Bilimler Enstitüsü, İstanbul.

Gümüşoğlu, F. (2008). Ders kitaplarında toplumsal cinsiyet. Toplum ve Demokrasi Dergisi, 2(4), 39-50.

Güney, N. (2016). 6. sınıf Türkçe ders kitaplarında toplumsal cinsiyet incelemesi. Turkish Studies International Periodical for the Languages, Literature and History of Turkish or Turkic, 11(3), 229-1248.

Güvenli, G. ve Uğur Tanrı̈ver, H. (2009). Ders kitaplarında toplumsal cinsiyet. G. Tüzün (Ed). Ders Kitaplarında Insan Hakları II: Tarama Sonuçları içinde (s. 97-114). Birinci Basım. İstanbul: Tarih Vakfi Yayınları.

Hayes, E. R. (2012). Kadınların öğrenmesine yeni bir bakış. Sayılan, F. (Ed.). Toplumsal cinsiyet ve eğitim: Olanaklar ve sinırlar içinde (s. 275-288). Ankara: Dipnot Yayınları.

İnal, K. (2004). Neoliberal eğitim ve yeni ilköğretim müfredatının eleştirisi. Praksis Dergisi, 14, 265-287.

Kalayc1, N. (2015). Analyses of the cartoon series from a gender equality perspective: Pepee. Educationand Science, 40(177), 243-270.

Kırbaşığlu Kılıç, L. ve Eyüp, B. (2011). İlköğretim Türkçe ders kitaplarında ortaya çıkan toplumsal cinsiyet roller üzerine bir inceleme. ODTÜ Sosyal Bilimler Enstitüsü Sosyal Bilimler Araştırmaları Dergisi, 2 (3), 129-148.

Kitiş Çınar, E (2013). Ortaokul Türkçe ders kitaplarında toplumsal cinsiyet. Yayımlanmamış Yüksek lisans tezi. T.C. Pamukkale Üniversitesi Eğitim Bilimleri Enstitüsü, Denizli.

Köseler, F. (2009). Okul öncesi öykü ve masal kitaplarinda toplumsal cinsiyet olgusu. Yayımlanmamış yüksek lisans tezi. Adnan Menderes Üniversitesi Sosyal Bilimler Enstitüsü, Denizli. 
MacNaughton, G. (2006). Constructing gender in early- years education. Skelton, C. , Francis, B. ve Smulyan, L. (Ed.).The Sage of handbook of gender and education içinde (127139). London: Sage Publication.

Metin, A. (2011). Kimliğin toplumsal inşası ve geleneksel kadın kimliğinin aktarımı. Çankırı Karatekin Üniversitesi Sosyal Bilimler Enstitüsü Dergisi, 2(1), 74-92.

Mineshima, M. (2008). Gender Representations in an EFL Textbook. 11/10/2017 tarihinde http://www.niit.ac.jp/lib/contents/kiyo/genko/13/14_MINESHIMA.pdf. adresinden erişilmiştir.

Mutluoğlu, A., Gökbaş, H. ve Kaleci, F. (2014). Ortaokul 5. sinıf matematik ders kitabı. Ankara: Pasifik Yayınları.

Oakley, A. (1972). Sex, gender and society. London: Temple Smith.

Özkan, R. (2013). İlköğretim ders kitaplarında kadın figürü. The Journal of Academic Social Science Studies, 6(5), 617-631.

Savaşkan, D. E. (Ed.). (2014). Ortaokul matematik 6. Sinıf ders kitabı. Ankara: Sevgi yayınları.

Sayılan, F. (2012). Toplumsal cinsiyet ve eğitim: olanaklar ve sinırlar. Ankara: Dipnot Yayınları.

Skelton, C. (2006). Boys and girls in elementary school. Skelton, C. , Francis, B. ve Smulyan, L. (Ed.).The sage of handbook of gender and education içinde (s. 139-152). London: Sage Publication Ltd.

Tanrı̈ver, H.U. (2003) Ders kitaplarında cinsiyet ayrımcılı̆̆ı. B. Çotuksöken, A. Erzan, O. Silier. (Ed.) Ders Kitaplarında Insan Hakları: Tarama Sonuçları içinde (s. 106-122). İstanbul: Tarih Vakf1 Yayınları.

Taylor, F. (2003). Content analysis and gender stereotypes in children's books. Teaching Sociology, 31 (3), 300-311.

Tezcan, M. (1985). Eğitim sosyolojisi. Ankara: Anı Yayıncılık.

Thompson, A. (2003). Caring in context: four feminist theories on gender and education. Curriculum Inquiry, 33, (1), 9-65.

Topal, Ö. (2012). Toplumsal cinsiyetin inşası: 7-12 yaş grubu örneği. Yayımlanmamış yüksek lisans tezi, Karadeniz Teknik Üniversitesi Sosyal Bilimler Enstitüsü, Trabzon.

Türkiye İstatistik Kurumu (TUIK), (2014). Gelir ve Yaşam Koşulları Araştırması Mikro Veri Seti (Kesit) 2012. Uluslararast Standart Meslek Siniflamast- ISCO 08. 09/06/2019 tarihindehttp://www.tuik.gov.tr/MicroVeri/GYKA_2012/turkce/metaveri/siiniiflamalar/i ndex.html adresinden alınmıştır.

Türköne, M. (1995), Eski Türk toplumunda cinsiyet kültürü. Ankara: Ark Yayınevi.

Ünal, C. (1994). Cinsiyete bağlı psikolojik farklar ve Türk çocukları üzerinde bir karşılaştırma. Ankara Üniversitesi Eğitim Bilimleri Fakültesi Dergisi,1(6), 1301-3718.

Van Dijk, Teun A. (1994) Söylemin yapıları ve iktidarın yapıları, M. Küçük (der ve çev.) Medya, İktidar, İdeoloji. Ankara: Ark yayınları.

Vatandaş, C. (2011). Toplumsal cinsiyet ve cinsiyet rollerinin algılanışı. Sosyoloji Konferanslar, $\quad O(35), 29-56.01 \quad$ Subat 2018 tarihinde http://dergipark.gov.tr/iusoskon/issue/9517/118909 adresinden alınmıştır.

Weitzman, L. J., Eiffel D., Hokada, E., ve Ross, C. (1972). Sex-role socialization in Picture books for preschool children. USA: American Journal of Sociology, 77, 1125.

Yavuzer, H. (2001). Çocuk Psikolojisi (Geliştirilmiş 20. Basım). İstanbul: Remzi Kitabevi.

Yaylı, D. ve Kitiş Çınar, E. (2014). Ortaokul Türkçe ders kitapları görsellerinde toplumsal cinsiyet. Turkish Studies - International Periodical For The Languages, Literature and History of Turkish or Turkic, 9(5), 2075-2096.

Yıldırım, A. ve Şimşek, H. (2013). Sosyal bilimlerde nitel araştırma yöntemleri (Genişletilmiş 9. Baskl). Ankara: Seçkin Yayıncılık.

Yorganc1, F. (2008). Illkögretim ders kitaplarında toplumsal cinsiyet rollerinin inşast. Yayımlanmamış yüksek lisans tezi, Afyon Kocatepe Üniversitesi Sosyal Bilimler Enstitüsü, Afyon.

Yurtsever, K. (2011). İlköğretim II. kademe öğretmenlerinin ögrencilere yönelik tutumlarının 
cinsiyet değişkenine göre incelenmesi. Yayımlanmamış yüksek lisans tezi. Dokuz Eylül Üniversitesi Sosyal Bilimler Enstitüsü Maliye Anabilim Dal, İzmir.

Zeenatunnisa, R. (1989). Sex discrimination in education: Content analysis of Pakistani school textbooks. Hage, Netherlands: Institute of Social Studies.

Zinec, A. (2000). Gender stereotypes in elementary school textbooks(Grades1, 4, 8). 19/02/2018 tarihinde http://osim.org.me/fosi_rom_en/downland/gender_stereotypes.pdf.adresinden alınmıştır. 


\section{Extended Abstract}

\section{Introduction/Purpose}

Inequality of opportunity means that individuals cannot benefit from some social rights equally. The differences in terms of gender, race, language, religion and social class are thought to cause these inequalities. In this study, it is emphasized that there are gendered elements in textbooks but many of us are not even aware of them and accept and internalize them.

The aim of this study is to examine the images presented in the secondary schools mathematics textbooks terms of gender. In the study, adult females and males, girls and boys within the visual items in the secondary school mathematics textbooks are examined in terms of "together with whom, from which sex, in which actions, in which places and in which occupations they are shown".

\section{Method}

The sample of the research is the visuals of the 5th, 6th, 7th and 8th grade secondary school mathematics textbooks of MEB used in İbrahim Karaoğlanoğlu Ortaokulu in Mersin City Toroslar District in the academic year of 2014-2015. The data in these documents were analyzed by content analysis method.

\section{Results}

As a result of the research, it was determined that secondary school mathematics textbooks also included sexist items. In this way, textbooks contribute to social reproduction of traditional gender relations. Images included in the mathematics textbooks are linked with the gender relations of adult females and males, boys and girls with whom, from which gender, in which actions, in which places and in which occupations. The most striking findings in the study are as follows: the percentage of adult men pictured alone is more than twice of the percentage of adult females pictured alone. In the case of the research in terms of children, the rate of girls pictured within their family is higher. When the 'gender of the persons with whom the children figures are shown' is examined, it is revealed that both the girl and the boy figures are mostly depicted with adult men and the figure of the girls pictured with their own gender is lower than that of the boys pictured with their own gender. Men are involved in more and various actions. The majority of these actions are work oriented, not depicted in any action directed towards home. Women are depicted more at home rather than at a job. When the professions of adult figures are examined, it is noteworthy that men' occupational fields are much wider than women. It is observed that most of the women in the books are represented as teachers, bankers, theaterists, trainers; and men are represented as athletes, teachers and coaches in turn. In the textbooks examined, it is seen that the number of male visuals in both adult males and boys is considerably higher than that of adult females / girls.

\section{Recommendations}

First of all, it is necessary to establish inter-institutional cooperation on gender inequalities and discrimination. Since gender inequalities represents other areas of social inequality, this needs to be accepted as a fundamental social problem, and then policies shoul be deveoped to prevent it.

Studies in literature show that gender stereotypes are still being reproduced and transferred through books in all over the world today. In order to prevent this, common efforts should be made in all countries and it is seen that there is a need for common education policies that will save women from their passive, limiting and disempowering positions. Here are many more things to do about the subject. For example, toys and textiles, especially for children, can be designed to create a sense of gender equality. Policies and practices can be developed to support women in both family and work life. Necessary policies and opportunities can be provided to increase the representation of women in social and political life, and egalitarian gender roles can be processed by considering educational problems in mass media such as television and radio.

First of all, books should be prepared considering the idea of raising awareness on gender equality and book review committees should be assigned to persons who are experts on gender discrimination. Those who prepare the textbooks should be more attentive in this regard and the 
textbooks should be revised in terms of gender equality. In addition, it is necessary to establish a commission to review the books in current use of the Ministry of Education and to change the books which have negative results in the commission reports.

Social structures in society can be seen as the main source of inequality, but gender discrimination can be prevented if nonsexist formal education is provided in schools and other educational settings. On the other hand, it is seen that teachers are the carriers of gender stereotypes. In order to raise awareness on this issue, teachers should be given in-service education on gender equality. In addition gender equality may be reinforced among objectives of the in-service training curriculum.

For the future studies it may be advisable to add new dimensions in analyzing gender issue in textbooks in addition to current study's categories. For example, the possible roles of adult figures and children can also be emphasized. In addition to the illustrations in the mathematics textbooks, the texts in the mathematics textbooks can also be examined. Limited number of studies has been carried out on gender in high school textbooks. In order to see the difference, gender issue can be investigated both in the visuals and texts in high school textbooks. Similarly, this study can be repeated in longitudinal designs. Thus, this can help to determine whether there is change in gender representations in textbooks. 